\title{
Relationship of Typical Core Temperatures After Hydrocooling on Retention of Different Quality Components in Sweet Cherry
}

\author{
Peter M.A. Toivonen ${ }^{1}$
}

ADDITIONAL INDEX WORDs. containerized shipping, export markets, ideal core temperature, Prunus avium, simulated shipping conditions, temperature logging cherries

Summary. The research was conducted to first determine the commercial reality in regards to effectiveness of hydrocooling of sweet cherries (Prunus avium) at commercial packing houses. Temperature data obtained from the commercial studies were then used as a guide to evaluate the effect of small differences $(0.5$, 3 , and $5{ }^{\circ} \mathrm{C}$ ) in sweet cherry core temperature on the quality retention of 'Sweetheart' sweet cherries over 6 weeks of storage to simulate container shipment. Sweet cherry core temperatures after in-line hydrocooling and the time of packing were generally around 3 or $5^{\circ} \mathrm{C}$. Once palletized and placed in commercial cold rooms, the internal boxes of a pallet did not cool any further. Only when a pallet was exposed to direct airflow from cooling coils did the exterior boxes in an assembled pallet show any further reduction in core temperature of packed sweet cherries. Experiments to evaluate the differences in quality retention at close to ideal core temperature $\left(0.5^{\circ} \mathrm{C}\right)$ vs. at more typical 3 or $5^{\circ} \mathrm{C}$ core temperatures demonstrated significant decline when the two higher temperatures were maintained over 6 weeks of storage. Sweet cherry firmness, titratable acidity, and stem removal force value declines in storage were significantly affected by these small differences in core temperature, showing the best retention at $0.5^{\circ} \mathrm{C}$. Stem browning increased significantly with 3 or $5^{\circ} \mathrm{C}$ storage by 6 weeks of storage. Decay was also significantly increased with warmer temperatures, but the results were variable likely due to differences in fruit infection at the time of harvest. Soluble solids were unaffected by storage temperature, and weight loss and pitting severity were somewhat affected. These results support the need for post packing cooling of sweet cherries as the core temperatures achieved by in-line hydrocoolers during packing do not reduce temperatures sufficiently to ensure good quality retention over longer periods of time that are required for container shipping to export markets. Therefore, forced-air cooling is recommended to further reduce sweet cherry temperatures in the box, before shipping.

$\mathrm{T}$ The effective handling of sweet cherries from production to purchase by consumer requires the understanding of quality change over the whole production-harvestmarketing continuum (Romano et al., 2006). Postharvest cooling is an important part of managing quality change and it has been extensively studied (Kupferman, 1995; Mattheis and Fellman, 2004; Stow et al., 2004; Young and Kupferman, 1994). However, the focus of the Canadian sweet cherry industry moved from relatively short shipping times by truck

Agriculture and Agri-Food Canada, Pacific Agri-Food Research Centre, Box 5000, 4200 Highway 97, Summerland, British Columbia, Canada V0H IZ0

Funding for the research was provided by Agriculture and Agri-Food Canada's Matching Investment Initiative and the British Columbia Cherry Association.

The authors would like to thank Brenda Lannard and Katie Lund for their technical assistance in conducting the experiments.

${ }^{1}$ Corresponding author. E-mail: peter.toivonen@agr.gc.ca. or air to long distance containerized shipping by ocean and requiring several weeks of good quality retention. Initial test runs by industry identified that understanding of cooling at a more detailed level had become necessary.

Cooling of sweet cherries is an important practice to ensure delivery of good quality at the market place (Mattheis and Fellman, 2004). All sweet cherry packing lines incorporate hydrocooling to reduce fruit temperature before packing within several minutes (Mattheis and Fellman, 2004), which is compatible with the required speed and throughput of a typical packing line. Many British Columbia packers have relied on either two- or single-stage hydrocooling to provide the sole cooling for sweet cherries. In two-stage hydrocooling, sweet cherries are cooled to between 8 and $10^{\circ} \mathrm{C}$ before placing on the sorting and packing line after which a second stage cools to the final temperature just before packing (personal observation). Single-stage cooling involves cooling to the final temperature just before packing and is only used in very small-scale packing lines.

The practice of relying just on hydrocooling is successful when sweet cherries are transported via air freight; however, there were questions as to its suitability for longer term shipping via ocean container. It is known that sweet cherries respire after packing, generating heat of respiration, and packed fruit can accumulate significant heat over time in long-term transport or storage, especially if they are not cooled to near $0{ }^{\circ} \mathrm{C}$ (Waelti, 1986). Therefore, experiments were conducted at packing house facilities throughout the British Columbia sweet cherry industry to determine core temperatures of fruit after cooling and packing in the box. Temperatures from the low, middle, and high end of the core temperatures measured in industry practice were used to test the significance of these temperature differences to quality of fruit from hydrocooled packed boxes in a simulated long-term container shipping experiment.

\section{Materials and methods}

All experiments were conducted using 'Sweetheart' cherries at commercial packing houses or using boxed fruit packed by the commercial packing houses. The packing houses were selected from the south, central, and north Okanagan Valley and a location in the Creston Valley of British Columbia to represent a cross section of the British Columbia industry.

\begin{tabular}{llll}
\hline $\begin{array}{l}\text { Units } \\
\begin{array}{l}\text { To convert U.S. to SI, } \\
\text { multiply by }\end{array}\end{array}$ & U.S unit & SI unit & $\begin{array}{l}\text { To convert SI to U.S., } \\
\text { multiply by }\end{array}$ \\
\hline 25.4 & inch $(\mathrm{es})$ & $\mathrm{mm}$ & 0.0394 \\
0.4536 & $\mathrm{lb}$ & $\mathrm{kg}$ & 2.2046 \\
1.1161 & $\mathrm{oz} / \mathrm{inch}$ & $\mathrm{g} \cdot \mathrm{mm}^{-1}$ & 0.8960 \\
$\left({ }^{\circ} \mathrm{F}-32\right) \div 1.8$ & ${ }^{\circ} \mathrm{F}$ & ${ }^{\circ} \mathrm{C}$ & $\left({ }^{\circ} \mathrm{C} \times 1.8\right)+32$
\end{tabular}


CONSTRUCTION OF TEMPERATURE LOGgING CHERRIES. Blush sweet cherries (from an advanced stage selection, 13N-10-09, from the Summerland Cherry Breeding Program, Summerland, BC, Canada) of $25 \pm$ $1.5 \mathrm{~mm}$ diameter were harvested and placed into cold storage for use as required. Blush sweet cherries were chosen since they are readily visible in the packing line and therefore easily retrieved once required data had been collected. The pit of the blush sweet cherry was excised using a scalpel, leaving a rectangular slot in the fruit $(\approx 5 \mathrm{~mm}$ wide $\times 12 \mathrm{~mm}$ long $\times 15 \mathrm{~mm}$ deep) large enough to accommodate a one-wire sealed-canister temperature logger (iButton ${ }^{\circledR}$ model DS1922L; Maxim Integrated, San Jose, CA). Before insertion of the one-wire canister into the blush sweet cherry, the unit was synchronized as per company instructions and a delayed start was invoked to initiate sampling at $0600 \mathrm{HR}$ the next morning via a contact receptor (Blue Dot ${ }^{\mathrm{TM}}$; Maxim Integrated, San Jose, CA) and using the software provided by the manufacturer (OneWire, Maxim Integrated). The sampling rate was set at $10 \mathrm{~s}$ to allow up to $23 \mathrm{~h}$ of data collection. The one-wire canister was then heat-sealed using a universal bench-mounted sealer (model 252; Clamco Corp., Cleveland, $\mathrm{OH}$ ) in a thin pouch of laminate film (PD941; Cryovac, Mississauga, ON, Canada) and inserted into the pitted blush sweet cherry. A piece $(5 \mathrm{~mm}$ wide $\times 12 \mathrm{~mm}$ long $\times 3 \mathrm{~mm}$ deep) excised from another blush sweet cherry fit over the rectangular slot and this was hotglued in place to encase the one-wire canister within the blush sweet cherry. The reconstructed blush sweet cherry was then sealed within a shrink film pouch using the bench-mounted sealer. The pouch was heated to shrink tightly around the blush sweet cherry using a heat gun (12.5 amps; Mastercraft, Toronto, ON, Canada). The assembled temperature logging cherries (TLCs) were then able to withstand handling, packing line operations, and hydrocooling while remaining intact, thus providing a good surrogate measure of sweet cherry core temperature. Equivalency of measurements to intact sweet cherry core temperatures was verified in laboratory tests (data not shown).

MEASUREMENT OF CORE TEMPERATURES OF COMMERCIALLY
PACKed SWEet CHERRIES. Two TLCS were warmed to ambient temperature and randomly placed in with harvested sweet cherries in picking containers during the harvest operation once per hour throughout the harvest day (i.e., a total of five times). They were allowed to move through the packing line with the harvested fruit and retrieved as they emerged from the end of the packing line. Retrieved TLCs were then cut open and the one-wire canister removed and the time stamp and temperature data downloaded via the contact receptor as described above. The minimum temperature the sweet cherries reached at the time of boxing was extracted, providing two separate measures for each of the five test times. The data from six packing houses was collected and average core temperatures at the time of packing calculated and maximum and minimum core temperatures achieved at each packing house determined.

MEASUREMENT OF CORE TEMPERATURES IN COLD-STORED PALLETS. Sweet cherry boxes $(10 \mathrm{~kg})$ were selected as they moved into the cold storage after packing and one TLC placed into each box. The boxes were then closed by the industry cold room staff and placed into pallets as they were being assembled. At the first packer, the boxes containing the TLC units were placed at an outside corner at the bottom layer of boxes, in the center of the pallet at the third layer of boxes assembled on the pallet, and at the outside corner on the fifth layer of boxes assembled on the pallet. The fully assembled pallet had nine layers of boxes. The cold room was set to $-1.7^{\circ} \mathrm{C}$, and the pallet was placed in the direct path of the airflow being blown from the refrigeration coils. At the second packer, all of the $10-\mathrm{kg}$ boxes containing TLC units were placed on the sixth layer of boxes in the assembled pallet. One box was located at the center of the layer, one was located at the front facing open cold room, one was located at one side facing open cold room, one was located at the back facing the cold storage wall, and the last was located on one side facing an adjacent pallet of sweet cherries. This second room was set at $0{ }^{\circ} \mathrm{C}$, and the pallets were not located in the direct path of the airflow being blown from the refrigeration coils.
Evaluating EFFeCT 0.5, 3, OR $5{ }^{\circ} \mathrm{C}$ STORAGE ON QUALITY RETENTION. 'Sweetheart' sweet cherries were collected from the end of the packing line from a local packing house. The grower had selected a maturity fruit skin color with using a comparator from the Centre Technique Interprofessionel de Fruits et Légumes (CTIFL, Paris, France), the target color range being between color chip numbers 5 and 6 . The sweet cherries were transported to the Pacific AgriFood Research Center, Summerland, $\mathrm{BC}$, Canada, within $1 \mathrm{~h}$ of packing in a refrigerated truck set at $5{ }^{\circ} \mathrm{C}$. Sweet cherries were repacked from five $10-\mathrm{kg}$ boxes into 0.5 -kg polystyrene clamshells. A total of five replicates per storage duration per storage temperature were packed into the clamshells, each replicate was selected from a different 10-kg box. Each of the clamshell containers was placed into an individual plastic film bag constructed from modified atmosphere box liner film (Lifespan; Amcor Flexibles, Moorabbin, Australia) and sealed by twisting the open side and fastening with a rubber elastic band. Atmospheres measured after 2 weeks of storage in these box liners when filled with 'Sweetheart' sweet cherries were $5.0 \% \pm 0.7 \%$ carbon dioxide $\left(\mathrm{CO}_{2}\right)$ and $12.3 \% \pm 1.3 \%$ oxygen $\left(\mathrm{O}_{2}\right)$.

Each clamshell was weighed at the time it was packed and then reweighed on the day that the sweet cherries were assessed for quality. Quality was assessed on week 0 ( $1 \mathrm{~d}$ after packing) and on weeks 1, 3, and 6. Severity of visual quality defects (pitting, decay and stem browning) was assessed using previously described hedonic scales (Kappel et al., 2002; Toivonen et al., 2004). Firmness was measured before and after storage using a FirmTech I testing instrument (BioWorks, Stillwater, $\mathrm{OK}$ ) as described by Kappel et al. (2002). Titratable acidity and soluble solids were measured (Kappel et al., 2002 ) and expressed as percentages.

Statistical analyses. Data were analyzed with SAS (version 9.1, SAS Institute, Cary, NC) using a general linear models procedure to determine differences in effects of storage period and temperature on quality change. The regression procedure was used to determine the coefficients of determination between 
storage temperature and quality measures at 6 weeks of storage.

\section{Results}

Measurement of CORE TEMPERATURES OF COMMERCIALLY PACKED SWEET CHERRIES. Average core temperatures of sweet cherries as they were packed in the box from six different packing houses ranged from 2.4 to $5.4^{\circ} \mathrm{C}$ with the majority of packing lines hydrocooling the cherries down to about $3{ }^{\circ} \mathrm{C}$ (Table $1)$. The range of maximum and minimum core temperatures at the time of packing indicated that cooling was not constant over a day of operation. Three packing houses showed a relatively narrow range in core temperatures $\left(2.1\right.$ to $\left.3.2^{\circ} \mathrm{C}\right)$ at the time of packing. These cooperators $(\mathrm{B}, \mathrm{D}$, and E) had similar average core temperatures and similar ranges in maximum and minimum core temperatures, suggesting that hydrocooler and packing line management can ensure reasonably consistent core temperatures. However, it is clear that a well-managed packing line cooling operation reliably reduced sweet cherry core temperature to $\approx 3^{\circ} \mathrm{C}$. It is important to note that the average measured water temperature in the hydrocoolers for all the packing houses in the study, over the course of the day, was $3.0 \pm 0.7^{\circ} \mathrm{C}$. This indicated that the sweet cherries had been in the hydrocoolers of each of the packing houses for sufficient times to effectively reduce the core temperatures to the lowest level possible.

MEASUREMENT OF CORE TEMPERATURES IN COLD-STORED PALlETS. Palletized boxes of sweet cherries generally did not show significant cooling in the center of the pallet when placed in a cold room (Fig. IA and B). When the palletized cherries were held in a very cold room and directly in the path of air flow from the refrigeration coil, during the first $20 \mathrm{~h}$, outer boxes in the pallet showed some cooling while none was detected in the interior boxes (Fig. 1A). If palletized cherries were placed into a cold room away from direct air flow from the cooling coils, there was no cooling effect in the pallet over $15 \mathrm{~h}$ in the cold room (Fig. 1B).

Evaluating EFFECT $0.5,3$, AND $5^{\circ} \mathrm{C}$ STORAGE ON QUALITY RETENTION. Core temperature of cherries stored in liners in $0.5,3$, or $5^{\circ} \mathrm{C}$ cold rooms were all $\approx 0.5{ }^{\circ} \mathrm{C}$ warmer than the cold room temperature (Fig. 2). Firmness, titratable acidity, stem browning, and stem removal force were all significantly influenced by storage temperature (Fig. 3), with

the colder temperature resulting in better firmness, less decline in titratable acidity and stem removal force, and a lower severity in stem browning at 6 weeks of storage. Weight loss was

Table 1. Core temperatures of 'Sweetheart' sweet cherries at the time of packing for six packing houses located in the Okanagan Valley and in Creston, British Columbia, Canada, for the 2008 harvest season. Average temperatures represent the average of two independent values obtained using temperature logging cherries at each of five times through one harvest day at each packing house.

\begin{tabular}{lcccccc}
\hline & \multicolumn{6}{c}{ Cooperating packing house } \\
\cline { 2 - 7 } & A & B & C & D & E & F \\
\hline Average core temperature $\left({ }^{\circ} \mathrm{C}\right)^{\mathrm{z}}$ & 5.4 & 2.6 & 3.0 & 2.4 & 3.0 & 4.3 \\
Maximum core temperature $\left({ }^{\circ} \mathrm{C}\right)$ & 6.6 & 3.1 & 4.6 & 3.1 & 3.2 & 5.6 \\
Minimum core temperature $\left({ }^{\circ} \mathrm{C}\right)$ & 2.6 & 2.1 & 1.6 & 2.1 & 2.1 & 2.6 \\
\hline
\end{tabular}

${ }^{\mathrm{z}}\left(1.8 \times{ }^{\circ} \mathrm{C}\right)+32={ }^{\circ} \mathrm{F}$.
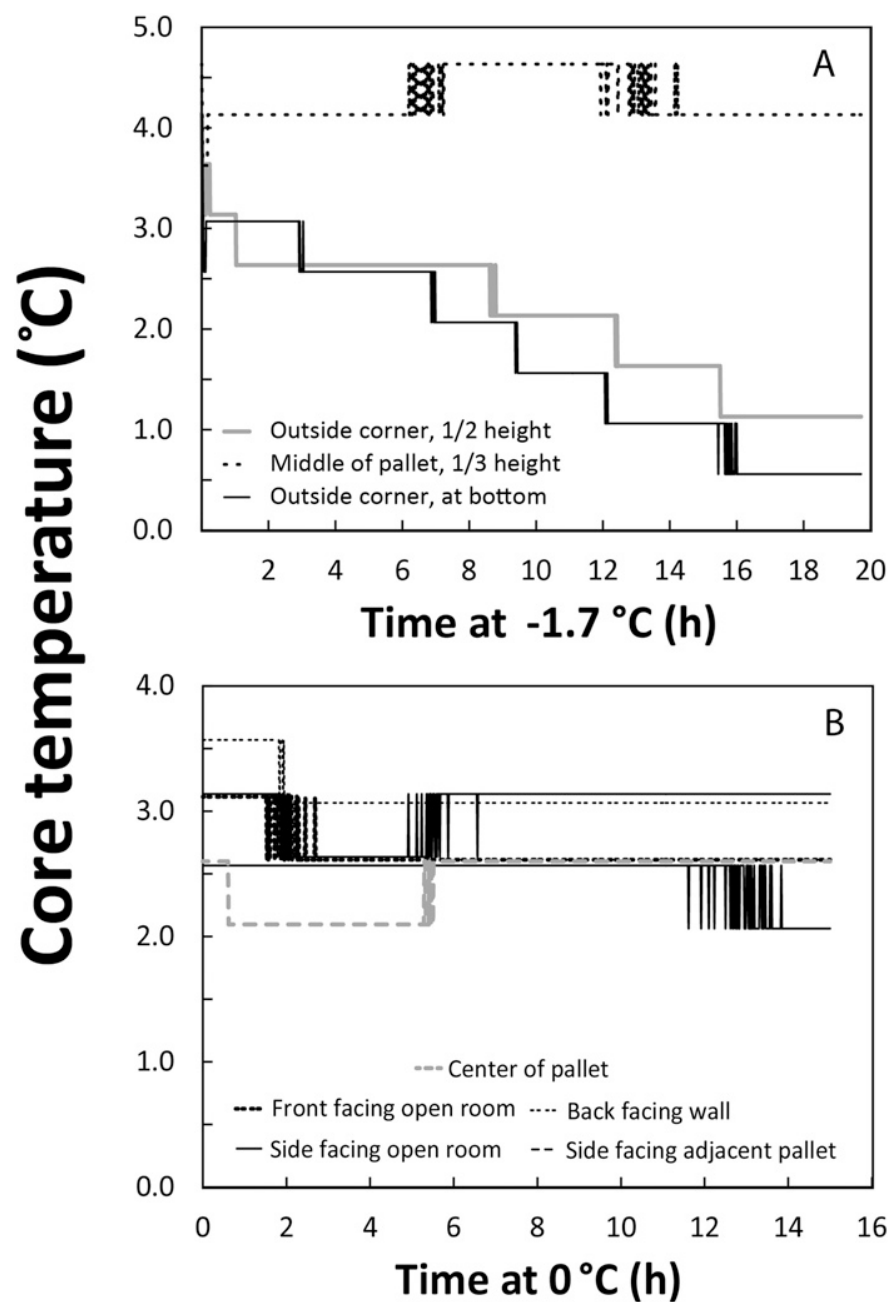

Fig. 1. Core temperature profiles of 'Sweetheart' sweet cherries in $10-\mathrm{kg}(22.0 \mathrm{lb})$ boxes over $15 \mathrm{~h}$ at two commercial cold storage rooms after palletizing into a nine layer pallets. Core temperatures were determined using temperature logging cherries (TLCs) containing one-wire canister temperature loggers (iButton $\AA$ model DS1922L; Maxim Integrated, San Jose, CA). One TLC was placed in each of the boxes that were located at either the center of the pallet or at outside faces of the pallet; $\left(1.8 \times{ }^{\circ} \mathrm{C}\right)+32={ }^{\circ} \mathrm{F}$. 


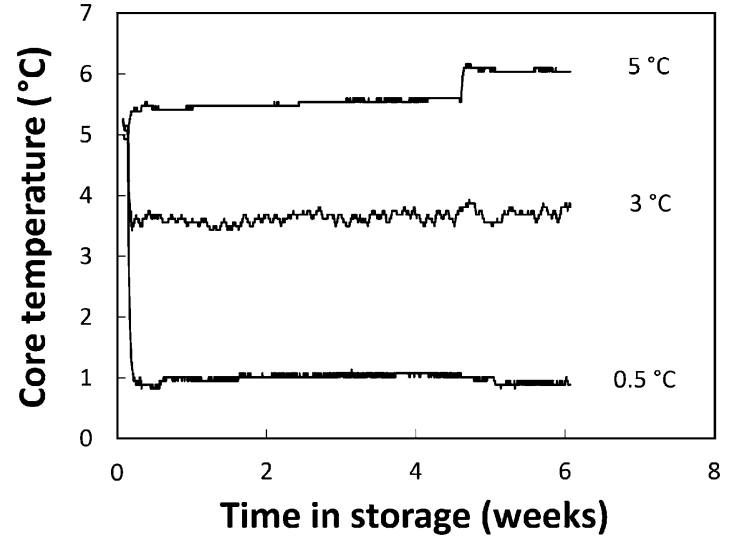

Fig. 2. Core temperature profiles of 'Sweetheart' sweet cherries in $0.5-\mathrm{kg}(1.10 \mathrm{lb})$ clamshells and sealed in cherry modified atmosphere box liners at $0.5,3$, or $5{ }^{\circ} \mathrm{C}$ for 6 weeks. Core temperatures were determined using temperature logging cherries (TLCs) containing one-wire canister temperature loggers (iButton ${ }^{\circledR}$, Model DS1922L, Maxim Integrated, San Jose, CA). One TLC was placed in each clamshell; $\left(1.8 \times{ }^{\circ} \mathrm{C}\right)+32={ }^{\circ} \mathrm{F}$.
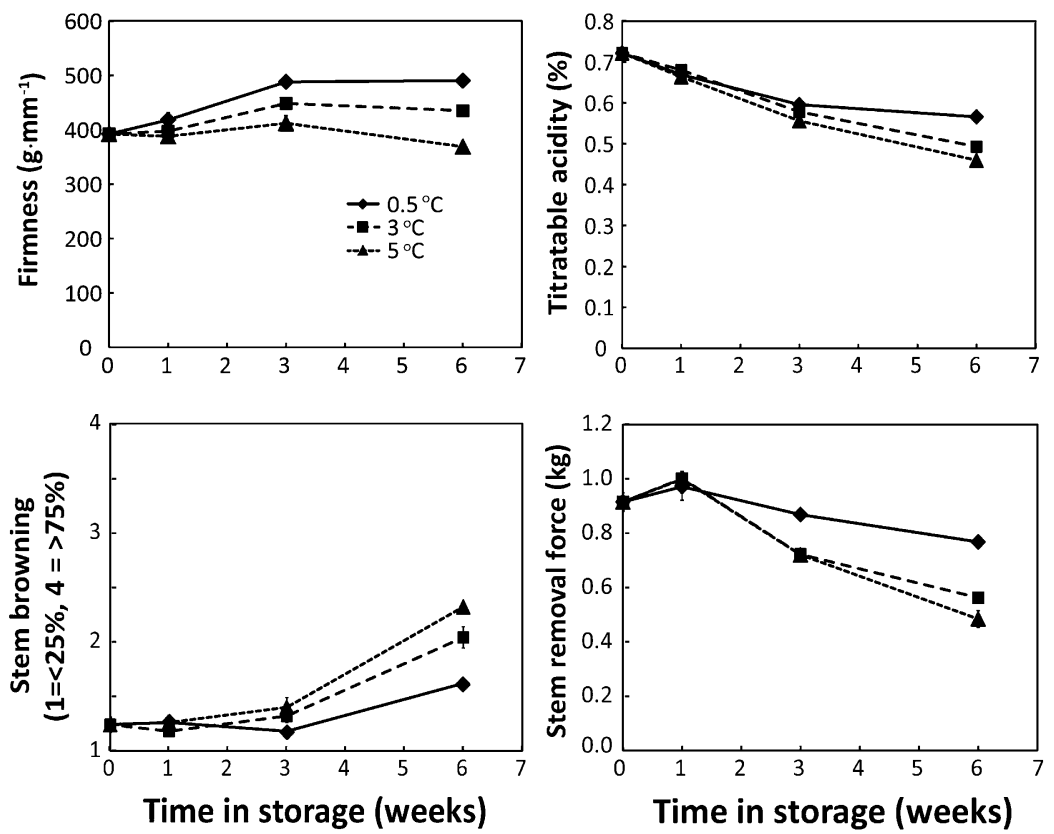

Fig. 3. Changes in average firmness, titratable acidity, stem browning severity, and stem removal force of 'Sweetheart' sweet cherries stored in $0.5-\mathrm{kg}$ clamshells and sealed in cherry modified atmosphere box liners at $0.5,3$, or $5{ }^{\circ} \mathrm{C}(32.9,37.4$, or $41.0^{\circ} \mathrm{F}$ ) for 6 weeks. Each data point represents a mean of five replicates \pm SE. Where an error bar is not visible, it is small and masked by the data point symbol; $1 \mathrm{~g} \cdot \mathrm{mm}^{-1}=$ $0.8960 \mathrm{oz} /$ inch, $1 \mathrm{~kg}=2.2046 \mathrm{lb}$.

moderately related to temperature by 6 weeks of storage $\left(R^{2}=0.42\right)$, but differences in severity of pitting were not significant (Fig. 4). Changes in soluble solids were not significant at any of the storage temperatures. Incidence of decay, while showing a strong relationship to storage temperature, also was quite variable with large standard errors at 6 weeks (Fig.
4). It should be noted that the core temperature of sweet cherries in the $5{ }^{\circ} \mathrm{C}$ room showed a jump near the end of 6 weeks storage (Fig. 2) and this coincided with an increase in decay recorded for those sweet cherries at 6 weeks.

Regression analysis confirmed that stem browning, stem removal force, firmness, and titratable acidity were all closely linked to storage temperature (Table 2). Soluble solids showed no linkage to storage temperature. Weight loss, decay, and pitting severity showed significant linkage to storage temperature but had much lower coefficients of determination.

\section{Discussion}

Temperature is well understood to be important for good quality retention in fruits and vegetables (Saltveit, 2004). However, discussion and research on temperature management has focused on large reductions of temperature and largely on control of storage room or shipping container temperature (Saltveit, 2004). This project showed that the core temperature of commercially hydrocooled fruit in palletized boxes was above the recommended temperature for sweet cherries (Mattheis and Fellman, 2004). Holding the sweet cherries in a cold room, even when it was set at below $0{ }^{\circ} \mathrm{C}$, could not further lower the core temperatures of the sweet cherries in inner cartons of palletized boxes and in another case, not even reduce the core temperature of sweet cherries in the exterior cartons of the pallet. This result is similar to results obtained in research on room cooling of packed 'Anjou' pears [ Pyrus communis (Faubion and Kader, 1997)]. The data showed that in practice, the best consistently achievable for sweet cherry core temperatures was $\approx 3{ }^{\circ} \mathrm{C}$ and that core temperatures could also be in the range of $5{ }^{\circ} \mathrm{C}$ or more in some situations. It is likely that these findings are not too different from what occurs in sweet cherry packing lines in other jurisdictions since the technology used in British Columbia is identical to that used in other sweet cherry growing area$s$ - the technology is now global in nature (personal observation). Recommendations for ideal storage/ shipping temperatures (Mattheis and Fellman, 2004) are based on experimental data, and it is the author's opinion that this work is the first to provide actual commercial temperature measurements for sweet cherry packing lines. Theoretically a hydrocooler, properly insulated and having excess cooling capacity, should be able to cool fruit to near $0{ }^{\circ} \mathrm{C}$. However, almost all commercial installations do not have the level of the insulation 

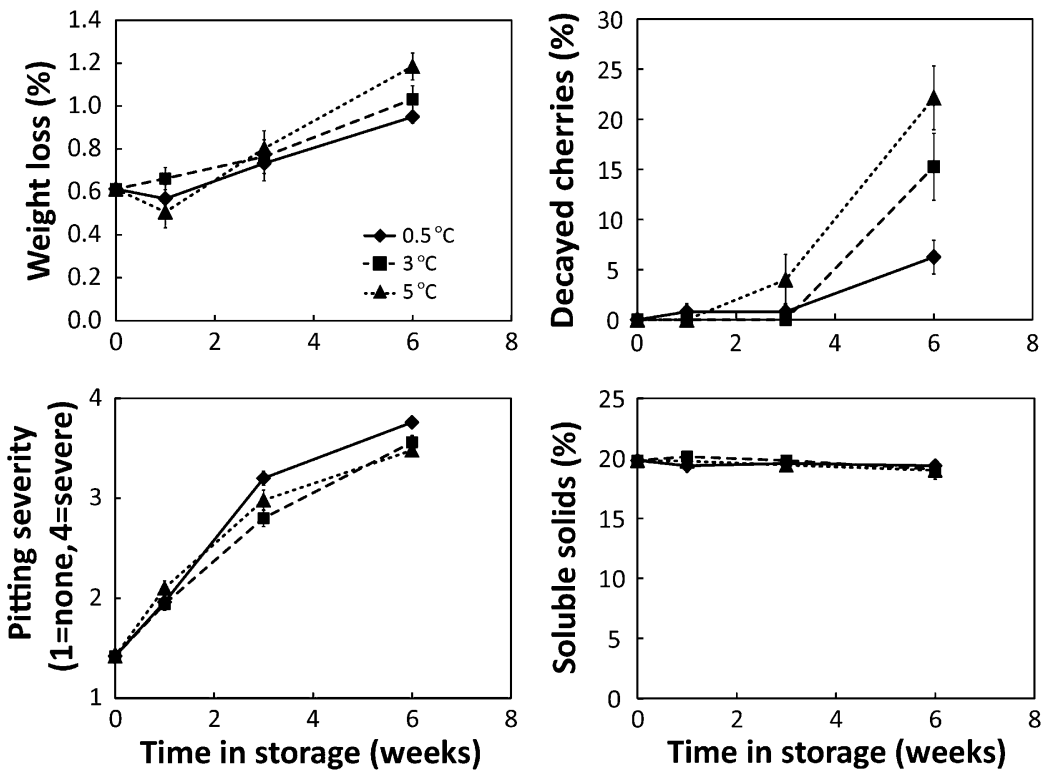

Fig. 4. Changes in average weight loss, decay incidence, pitting severity, and soluble solids content of 'Sweetheart' sweet cherries stored in $0.5-\mathrm{kg}(1.10 \mathrm{lb})$ clamshells and sealed in cherry modified atmosphere box liners at $0.5,3$, or $5^{\circ} \mathrm{C}(32.9,37.4$, or $41.0^{\circ} \mathrm{F}$ ) for 6 weeks. Each data point represents a mean of five replicates $\pm \mathrm{SE}$. Where an error bar is not visible, it is small and masked by the data point symbol.

Table 2. Coefficients of determination between storage temperature and quality or defect measures of 'Sweetheart' sweet cherries at 6 weeks of storage at 0.5 , 3 , or $5^{\circ} \mathrm{C}\left(32.9,37.4\right.$, or $\left.41.0^{\circ} \mathrm{F}\right)$ in modified atmosphere cherry box liners.

\begin{tabular}{lcr}
\hline Quality measure & $\boldsymbol{R}^{2}$ & \multicolumn{1}{c}{$\boldsymbol{P}>\mathbf{F}$} \\
\hline Weight loss & 0.42 & 0.0086 \\
Decay & 0.57 & 0.0012 \\
Pitting & 0.48 & 0.0042 \\
Stem browning & 0.84 & $<0.0001$ \\
Stem removal force & 0.83 & $<0.0001$ \\
Firmness & 0.90 & $<0.0001$ \\
Soluble solids content & 0.02 & 0.6352 \\
Titratable acidity & 0.82 & $<0.0001$ \\
\hline
\end{tabular}

required to prevent warming of hydrocooler water and the volumes of warm fruit placed into the hydrocooler on a constant operational basis prevent the theoretical temperature reduction to levels recommended. The author's opinion is supported by the fact that the average core temperatures of the sweet cherries at the time of packing was similar to average hydrocooler water temperatures measured at those packing houses $\left(3^{\circ} \mathrm{C}\right)$. This article presents a realistic perspective on temperatures in the commercial sweet cherry packing industry that has not been published previously.
Small increments in core temperature $\left(2\right.$ to $2.5^{\circ} \mathrm{C}$ ) could mean large and significant differences in quality retention for sweet cherries stored up to 6 weeks. Previously, the export of British Columbia sweet cherries was via air shipments, which ensured that the product reached the market several days after harvesting and packing. However, the adoption of container shipping where transit time can range from 2 to 5 weeks after packing, has required a reexamination of the importance of such small differences in temperature. The results clearly show that the most important quality attributes (firmness, stem browning, stem removal force, titratable acidity, and decay incidence) are all significantly influenced by small differences in temperature. An increment in core sweet cherry temperature as small as 2 to $2.5^{\circ} \mathrm{C}$ led to significant reduction in quality. The temperature closest to ideal was $0.5{ }^{\circ} \mathrm{C}$, and sweet cherries stored at that temperature showed remarkably good quality retention up to 6 weeks in storage. Despite using $0.5 \mathrm{~kg}$ size packages in modified atmosphere packaging, sweet cherries from all the storage temperatures had core temperatures that were $\approx 0.5{ }^{\circ} \mathrm{C}$ higher than the cold room temperature, indicating that heat of respiration was exerting a significant influence on sweet cherry core temperature and this phenomenon has been reported previously (Saltveit, 2004; Waelti, 1986). Thus, there is a concern that temperatures of sweet cherries increase over time in much larger masses such as full pallets that are in tightly packed containers during transit as suggested by Kupferman (1995) and Waelti (1986).

This work clearly shows that temperature management of sweet cherries for long-term containerized shipment requires attention to very small differences in temperatures. A deviance of temperature as little as a few degrees Celsius can result in dramatically different outcomes for the most important quality indicators of sweet cherry. Thus sweet cherries must be cooled after packing to bring their temperature down to a value that will ensure the best quality at distant markets when shipped by container. This can best be accomplished by forced-air cooling of palletized boxes as suggested by Kupferman (1995).

\section{Literature cited}

Faubion, D.F. and A.A. Kader. 1997. Influence of place packing or tray packing on the cooling rate of palletized 'Anjou' pears. HortTechnology 7:378382 .

Kappel, F., P. Toivonen, D.-L. McKenzie, and S. Stan. 2002. Storage characteristics of new sweet cherry cultivars. HortScience 37:139-143.

Kupferman, E.M. 1995. Cherry temperature management. Tree Fruit Postharvest J. 6:3-6.

Mattheis, J. and J. Fellman. 2004. Cherry (sweet). In: K.C. Gross, C.Y. Wang, and M. Saltveit. U.S. Dept. Agr. Hdbk. No. 66. The commercial storage of fruits, vegetables, and florist and nursery stocks. 23 June 2014. <http://www.ba.ars.usda.gov/ hb66/052 cherry.pdf>.

Romano, G.S., E.D. Cittadini, B. Pugh, and R. Schouten. 2006. Sweet cherry quality in the horticultural production chain. Stewart Postharvest Rev. 6:1-7.

Saltveit, M.E. 2004. Respiratory metabolism. In: K.C. Gross, C.Y. Wang, and M. Saltveit. U.S. Dept. Agr. Hdbk. No. 66. The commercial storage of fruits, vegetables, and florist and nursery stocks. 23 June 2014. <http://www.ba.ars.usda.gov/ hb66/019respiration.pdf>. 


\section{Research Reports}

Stow, J.R., J. Jameson, and K. Senner. 2004. Storage of cherries: The effects of rate of cooling, store atmosphere and store temperature on storage and shelf-life. J. Hort. Sci. Biotechnol. 79:941-946.

Toivonen, P.M.A., F. Kappel, S. Stan, D.-L. McKenzie, and R. Hocking.
2004. Firmness, respiration and weight loss of 'Bing', 'Lapins', and 'Sweetheart' cherries in relation to fruit maturity and susceptibility to surface pitting. HortScience 39:1066-1069.

Waelti, H. 1986. Forced air cooling of cherries. Postharvest Pomol. Nwsl. 4(1). 23
June 2014. <http://postharvest.tfrec. wsu.edu/pages/N4IIA $>$.

Young, C. and E. Kupferman. 1994. Infield hydrocooling-Cherry temperature management. Tree Fruit Postharvest J. $5: 20-21$. 